\title{
Managing Bees for Delivering Biological Control Agents and Improved Pollination in Berry and Fruit Cultivation
}

\author{
Heikki M. T. Hokkanen ${ }^{1}$, Ingeborg Menzler-Hokkanen ${ }^{1} \&$ Marja-Leena Lahdenperä ${ }^{2}$ \\ ${ }^{1}$ Department of Agricultural Sciences, University of Helsinki, Finland \\ ${ }^{2}$ Verdera Oy, Espoo, Finland \\ Correspondence: Heikki M. T. Hokkanen, University of Helsinki, Finland. E-mail: heikki.hokkanen@helsinki.fi
}

Received: March 11, 2015 Accepted: May 3, 2015 Online Published: June 20, 2015

doi:10.5539/sar.v4n3p89 URL: http://dx.doi.org/10.5539/sar.v4n3p89

\begin{abstract}
Targeted precision biocontrol and improved pollination were studied Europe-wide in the EU ERA-NET CORE ORGANIC 2 project BICOPOLL (Biocontrol and Pollination). A case study was conducted on the management of strawberry grey mold Botrytis cinerea, with the biocontrol fungus, Gliocladium catenulatum, vectored by honey bees or bumble bees. A joint field trial carried out in five countries targeted strawberry cultivations in open field, and included four treatments: untreated control, chemical fungicide, entomovectored biocontrol, and chemical and biocontrol combined. In organic fields, no pesticide treatments were included. The proportion of moldy berries, and/or the marketable yield of healthy berries were recorded from each treatment, along with other parameters of local interest. A pilot study was started in Finland in 2006, and, by 2012, large commercial farms were using entomovectoring. In 2012, field trials were started in Estonia and in Italy, and in 2013-14, these experiments were expanded to Slovenia and Turkey. In total, 26 field tests were conducted using entomovectoring and Gliocladium catenulatum (Prestop ${ }^{\circledR}$ Mix) on strawberry, with five additional trials on raspberry. Efficacy results have been excellent throughout the field studies. The results show crop protection equalling or exceeding that provided by a full chemical fungicide program, under all weather conditions, and over a wide geographical range (from Finland to Turkey). Under heavy disease pressure, entomovectoring provided on average a $47 \%$ disease reduction, which was the same as multiple fungicide sprays. Under light disease pressure, biocontrol decreased grey mold by an average of $66 \%$, which was greater than fungicide sprays The concept has proven to be effective on strawberries, raspberries, pears, apples, blueberries, cherries, and grapes. A conservative estimate for Finland is that over 500 ha of strawberry cultivation currently use the technique $(\approx 15 \%$ of the strawberry growing area). To make full use of the entomovectoring technique, organic berry and fruit growers are encouraged to (i) keep bees, or to hire the service from local beekeepers for entomovectoring; and (ii) manage vegetation within and around the target crop to support the activity of bees and other pollinators, which can help to disseminate the beneficial microbial populations within the crop. Beekeepers are encouraged to (i) market pollination and biocontrol services to fruit and berry growers, and (ii) ensure that all operations are effective in mananging bees and their microbe dissemination activity. Biocontrol product manufacturers are encouraged to further develop products and their formulations specifically for entomovectoring, because current formulations are suboptimal as they are initially optimized for other uses (e.g., mixing into the soil).
\end{abstract}

Keywords: antagonist, Apis mellifera, biological control, Bombus, Clonostachys rosea, dispenser, entomovectoring, fungal diseases, Fusarium avenaceum, organic production

\section{Introduction}

\subsection{Constraints Facing Organic Berry Producers in the EU}

Organic berry and fruit production suffers heavily from the lack of effective disease and pest management tools, and from inadequate insect pollination at times. As a consequence, the expanding demand on organic berries and fruit cannot be satisfied today (European Commission, 2014). In our study we focused on the grey mold caused by Botrytis cinerea on strawberry and raspberry, with an additional pilot study on apple. The EU is the biggest producer of strawberries in the world, and of the single member countries, Spain is number two producer after the USA (FAO, 2011). Turkey is the third most important strawberry producer in the world, and of the other countries involved in the BICOPOLL project, Italy is 9th, Germany 10th, and Belgium 19th in global strawberry 
production. In total, strawberry area in the EU was 111,801 ha in 2008 (FAO, 2011). In terms of economic importance, strawberry is the 12th most valuable agricultural commodity in Finland (after animal-based products such as meat, milk, and eggs, and barley, wheat, oats, potato and rapeseed), and ranks similarly among the top 20 agricultural commodities in Germany (15th), Estonia (15th), and Belgium (16th).

Organic strawberry growing has rapidly expanded in Europe. Grey mold (Botrytis cinerea) is the most important biotic threat to the crop, and conventional growing methods with fungicides usually require 3-8 treatments per season, depending on weather conditions. The industry is concerned about the slow progress in the development of biological control methods (biofungicides) against Botrytis (Agriculture and Agri-Food Canada, 2009), as the chemical fungicides rapidly lose their ability to control the disease. Currently organic strawberry growers have no means of preventing grey mold on their crop, and consequently, they occasionally lose the harvest almost entirely. Conventional growers suffer, on average, $10-20 \%$ pre-harvest crop losses to grey mold (Stromeng, 2008), and up to 25-35\% (IPM-Centers, 2011), despite the numerous fungicide treatments.

Early trials on biological control of Botrytis have relied on spraying biocontrol agents (BCA) on strawberry flowers. Extensive field trials in Finland showed that three spray applications with Prestop ${ }^{\circledR}$ (Verdera Oy, Espoo, Finland) formulation at flowering time remarkably decreased the number of moldy berries and increased the marketable yield (Lahdenperä, 2006). However, despite the efficacy of Gliocladium sprays against Botrytis, the method could not be widely used because of high treatment costs. Blanket spraying could not be adjusted to deliver the BCA only to the inflorescence, at the different developmental stages of flowers, and within the required time frame to prevent grey mold growth. In contrast, bees, as an essential component of the pollination system, can colonize the flowers with the BCA and achieve disease suppression naturally, via frequent pollination visits to each inflorescence at the proper time.

\subsection{Pollinators in Biological Control Dissemination}

The use of pollinating insects for the biological control of plant diseases and pests has its origins in the early 1990s (Peng et al., 1992), when honeybees were first used to disseminate biological control agents to strawberry flowers as a replacement for insecticides. Subsequently the concept was termed 'entomovector technology' by Hokkanen and Menzler-Hokkanen (2007), and a more systematic development of the pollinator-and-vector technology was established. This environmentally friendly control strategy, where control agents against plant pathogens and insect pests, are delivered directly onto crop flowers, while simultaneously fulfilling the pollination requirement, represented an innovative way of crop protection for organic as well as conventional cropping systems. Because the appropriate BCA is colonizing the flowers, natural disease suppression is achieved as a consequence of the frequent pollination visits at each inflorescence (Smagghe et al., 2012). The unique concept of entomovectoring incorporates several ecological components, including pollinators, biocontrol agents, and plant pathogens and/or insect pests (Kevan et al., 2008). However, its success is based on mutual and compatible interactions between the appropriate components of the vector, control agent, formulation, and dispenser, and the safety of the environment and human health, in particular the operator/manager at the farm.

One of the reasons which has led to the development of the entomovectoring technology as a biocontrol strategy was the need to reduce the application of environmentally harmful synthetic pesticides. Concerns regarding the impact of conventional chemical pesticides on human health and the environment, and the development of resistance by pests, have led to the search for alternative methods. Also, biological control methods, where BCAs have been used as conventional applications (e.g., biofungicides), often have resulted either in poor control, or in too high application costs, resulting in slow progress towards an ideal system. The entomovectoring technology represents a promising alternative, wherein pollinators achieve a dual role: control agents are directly delivered on the target location (i.e., the flowers), while the pollination needs are fulfilled (Mommaerts \& Smagghe, 2011). In this way the BCA forms an effective disease and pest management tool during flowering of the crop, and during the development of fruits, since the flowers are the main location of infection by plant pathogens (e.g., $B$. cinerea) and insect pests (e.g., the western flower thrips Frankliniella occidentalis). Control of these infections by the entomovector technology can thus increase marketable fruit and berry yields (Mommaerts et al., 2011), and even play a role in controlling post-harvest diseases, such as Alternaria alternata (Nallathambi et al., 2009).

Despite the promising results of the first studies on the use of pollinating insects to spread the BCA to fruit flowers, the practical adoption of this approach by the growers has progressed slowly. The CORE ORGANIC 2 (EU ERA-NET) project BICOPOLL was designed to tackle this lack of uptake, and to provide a pan-European case study on protecting organic strawberry from its most important disease, the grey mold, by entomovectoring using the fungal antagonist Gliocladium catenulatum (Prestop ${ }^{\circledR}$ Mix). In addition, the project investigated possibilities of expanding the use of the concept into other berry and fruit growing systems. A pilot study for the 
control of the core rot of apple (Fusarium avenaceum and B. cinerea) was included in 2013-2014.

To our knowledge, this is the first time the entomovectoring technique has been tested on apple. The problem to be solved is a storage disease, core rot, which infects apples through the flowers. The symptoms may sometimes appear at harvest, but most often the disease occurs only after storage. Certain apple varieties, e.g., 'Rubinola', 'Gala Schnitzel' and 'Santana' are very susceptible to core rot. Appropriate chemical control of this disease is not available.

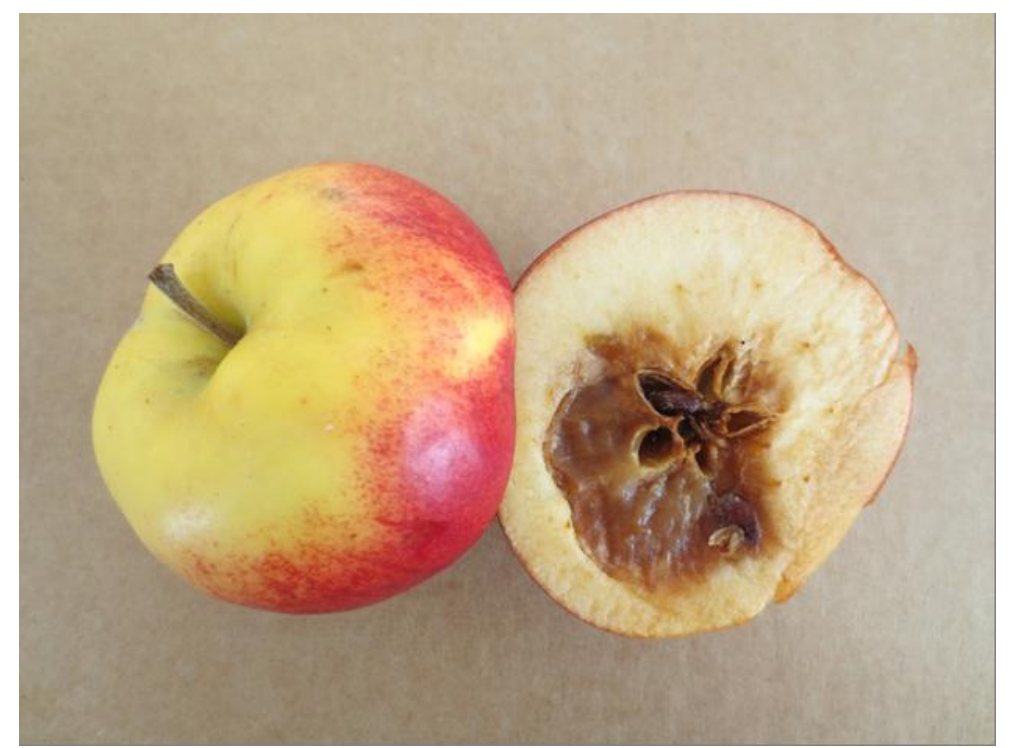

Figure 1. Core rot symptoms caused by Fusarium avenaceum on the apple variety 'Santana', which is sensitive to the disease

Photo: Marja-Leena Lahdenperä, Verdera Oy.

\section{Methods}

\subsection{Case Study on Biocontrol of Grey Mold on Organic Strawberry and Raspberry}

Targeted precision biocontrol and improved pollination were studied first in a pilot project in Finland (2006-2009), followed by the Europe-wide project BICOPOLL in 2011-2014. We chose to focus as a case study the control of strawberry grey mold, Botrytis cinerea, with the biocontrol fungus, Gliocladium catenulatum, vectored by honey bees or bumble bees. The joint trial targeted strawberry cultivations in the open field, and included four treatments: untreated control, chemical fungicide, entomovectored biocontrol (Prestop ${ }^{\circledR}$ Mix), and chemical and biocontrol combined. Wide variety of fungicides was involved, according to the regulatory approval and local practices in each country; typically 3-5 different fungicide treatments were used at 2-4 day intervals during flowering. Each active ingredient was used only once per season. In organic fields, no pesticide treatments were included. In 2010 and 2011, field trials were conducted in Estonia, and in 2012, in Italy - in addition to Finland, where large commercial farms used entomovectoring after the pilot study. In 2013, the experiments were expanded to Slovenia and Turkey, and were completed in 2014.

The biocontrol agent for all trials was the commercial preparation of Gliocladium catenulatum, "Prestop ${ }^{\circledR}$ Mix", which was sent to all partners in sufficient quantity for the trials each year. Common parameters across all field trials are detailed in Table 1. As most trials were conducted on operational, commercial farms, local adjustments were made to the experimental plan as needed. In total, we report in this paper the results from 26 separate field experiments on strawberry in five countries between 2006 and 2014. In addition, the same experimental protocol was used on five raspberry fields in 2007 in Finland. 
Table 1. Common parameters for strawberry entomovectoring field trials, and instructions to operators

\begin{tabular}{llll}
\hline Parameter & Preferred minimum set-up & Deviations if needed & Remarks \\
\hline Type of field & $\begin{array}{l}\text { Organic strawberry in } \\
\text { commercial farm setting }\end{array}$ & $\begin{array}{l}\text { (i) test fields of a research If conventional growing is } \\
\text { farm, or (ii) conventionally } \\
\text { grown strawberry with no fungicide spray is } \\
\text { allowed on the assessment } \\
\text { minimum pesticide use }\end{array}$ & $\begin{array}{l}\text { plots: cover these with } \\
\text { plastic sheets during } \\
\text { spraying if needed }\end{array}$
\end{tabular}

Size of field One hectare for the Smaller area can be used, BICOPOLL project (two but then the "bee" or "hive beehives per ha); sampling density" per ha will be from $2 \mathrm{~m} \times 2 \mathrm{~m}$ plots

Surroundings of As little competing flowering field plants close to the field as possible

Treatments

1) untreated control

2) entomovectored treatment using Gliocladium catenulatum (Prestop ${ }^{\circledR}$ Mix) and honey bees

Plot sizes

Minimum: $2 \mathrm{~m}$ x $2 \mathrm{~m}$

$\begin{aligned} & \text { Number } \\ & \text { replicates }\end{aligned}$ of 4
treatment

Placement of bee At the edge of the strawberry hives

Properties of hive

Prestop ${ }^{\circledR} \quad$ Mix $\quad$ Start after the first flowers are flowers); stop when the main flowering period is over higher

Add "extra pollination only" (by honey bees) if possible: plots with exclusion cages, and daily dose of honey bee foragers without Prestop ${ }^{\circledR}$ Mix, added for pollination

More is better, if possible field so that they can easily be operated; can be next to each other. Place them a little above the ground (10-30 cm min.)

A "strong" but "relatively Larger hives are also OK small" hive is preferred. Healthy colony with large brood area and low pollen stores. dissemination open (about 5-10\% of

If the total strawberry area is much larger, more hives and dispensers are needed

Bee-attractive vegetation can be within the field, e.g. white clover between rows

Other treatments can be added as each project partner wishes. Untreated controls must be covered with light exclusion cages during the bee dissemination period.

For treatment 2 clearly marked plots in the open field are needed; treatment 1 plots must exclude bees

Dosing and timing

Apply daily about 3-4 mm layer of Prestop ${ }^{\circledR}$ Mix in the dispenser (about $5 \mathrm{~g}$ ), early in the morning; $200 \mathrm{~g}$ in total /
Bring the hives there at the start of the experiment, not earlier if feasible.

"Small" hive $=$ about 5000 adult workers and a 15000 worker brood at the start of flowering

Place the exclusion cages over the control plots as you start the dissemination; first let the bees 'learn' to use the dispenser without Prestop ${ }^{\circledR}$ Mix for 2-3 days, and then start to disseminate. REMOVE the exclusion cages as you stop the dissemination at the end of flowering.

Train the grower to do this, if feasible. Use protective gear as a rule. Do not apply if the weather is very 
dispenser; $400 \mathrm{~g} /$ ha during the whole flowering period

Data/samples to be collected

Map the vegetation, and in particular the flowering plants attractive to honey bees, within $1 \mathrm{~km}$ of the field

If possible, monitor occasionally flower visits of honey bees on the strawberry flowers; quantify for brief periods (10-20 minutes)

Effect of treatment: measure (a) marketable yield and

(b) moldy berry yield for each treatment plot and replicate. Collect berries from $1 \mathrm{~m}$ of strawberry row (or from a fixed number of consecutive berry bushes) from each plot into separate collection baskets (healthy, moldy) and weigh them immediately. Apply minimum size for acceptable berry (10-mm diameter). Collect every two days, or as customary at the farm. Finish data collection when the grower does not harvest any more strawberries

rainy.

Smaller area is also OK

If you have time and resources, you can collect flower samples and try to study the amount of Gliocladium spores on them, from the different treatments. This has been difficult to do accurately (but see Mommaerts et al. 2011 for selective media and plating techniques).
No detailed assessment is necessary (estimated size of ground cover of the most important plants; a rough 'map' is best)

Not needed if not feasible to do

As this trial is mostly for demonstration purposes, effect on marketable yield is the most relevant measure of success. If we at some study sites can separate the impact of improved pollination from the impact of disease control, even better (with a set of extra exclusion cages and using bees without Prestop ${ }^{\circledR}$ Mix).

\subsection{Case Study on Apple Trees in Finland}

The apple trial was carried out in 2013 in collaboration with the manufacturers of Prestop ${ }^{\circledR}$ Mix (Verdera Oy), the advisory service group Pro Agria Ålands Hushållningssällskap (Pernilla Gabrielsson), and Peter Sundin's \& Margareta Björkén's commercial apple orchard in the Åland Islands, Finland. The orchard was managed by conventional methods (i.e., synthetic pesticides were used according to typical practices simultaneously with the biological control (Prestop ${ }^{\circledR}$ Mix entomovectoring). The synthetic pesticides were applied against other pests, such as apple scab (Venturia inaequalis).

\subsubsection{Field Trial Arrangements 2013}

Since the trial was carried out in a conventional orchard, the experimental arrangements included one area where the honeybee-disseminated biocontrol was used, and a similar area which served as the untreated control. These two areas, separated by a small forest, were located far enough apart that bees delivering Gliocladium were not likely to fly from the treated area to untreated apple trees. The test was carried out with the winter variety, 'Rubinola', which is sensitive to core rot. Two beehives equipped with a BeeTreat ${ }^{\circledR}$ dispenser (Aasatek Oy, Finland; see Smagghe et al., 2012) were placed at the edge of the apple orchard about 50m from the test apple tree rows. Upon exit from the hive, bees had to cross an inoculum field in the dispenser, thus picking up the biocontrol agent spores on their body hairs. Prestop ${ }^{\circledR}$ Mix powder was applied every day with a spoon onto the inoculum field, about $5 \mathrm{~g}$ at a time, and spread evenly over the field resulting in a 2-4 mm thick layer. This was done around $8 \mathrm{a} . \mathrm{m}$. for the entire flowering period. Unfortunately, flower samples for Gliocladium analysis were not collected in the first test year.

\subsubsection{Apple Storage Trial in 2013-14}

The field trial then continued as a test against storage disease: In the beginning of October, externally healthy apples were harvested into four boxes holding $5 \mathrm{~kg}$ each (about 30-35 apples per box), for storing until January and February. At the end of the storage period, final evaluation of apple quality and disease damage was 
conducted. The quality was assessed by grouping the apples in three categories: (i) Grade One (EVIRA, 2009), (ii) affected by core rot, and (iii) other damages. To be able to make observations on the internal core rot symptoms, the apples were cut in half. In addition, several pathogen identifications from diseased apples using standard agar-plate isolation techniques (Narayanasamy, 2011) to determine the causative agents of the core rot, were carried out in the laboratory of Verdera Oy, Espoo, Finland.

\subsubsection{Apple Field Trial Arrangements in 2014}

Based on the promising results obtained in 2013-14, the study was continued by establishing a new field trial in spring 2014 in the same apple orchard. The arrangements were similar to those in the previous year, but the winter variety, 'Zari', was used as the test fruit because this variety was growing closer to the beehives than 'Rubinola' (the previous year's variety). 'Zari' is also sensitive to core rot. There were five beehives placed at the edge of the orchard, but only two of them were equipped with a microbe dispenser. These two were located close to the apple tree rows (at 10-m distance). The other end of the rows was at a distance of $100 \mathrm{~m}$. Daily filling of the dispenser with about $5 \mathrm{~g}$ of Prestop ${ }^{\circledR}$ Mix powder per day began on the 22nd of May, and continued until the end of the flowering period. Harvest was completed in early October.

\subsubsection{Sampling of Flowers}

Flower samples were taken at full bloom, i.e., 10 days after the beginning of honeybee-delivery of the biofungicide. Flowers were sampled in a laboratory analysis to assess the colonization by G. catenulatum. Flower samples of treated trees were taken at 3 distances from the hive, from 2 apple trees per distance and 10 flowers/tree, or 60 flowers in total. To ascertain that Prestop $\left.{ }^{(}\right)$Mix had not been carried by bees to the untreated reference area, 10 random flower samples were collected also from trees grown in the area where entomovectoring of Prestop ${ }^{\circledR}$ Mix had not been used. Flowers were collected at the fully open stage and samples were packed in small plastic tubes, 1 flower per tube. For the transport from the orchard to the lab at Verdera Oy, Espoo, Finland, the sample tubes were packed in a polystyrene box with an ice pack.

\subsubsection{Laboratory Analysis}

From each flower, 15 stamens were plated on water agar (Figure 2) and other flower organs (petals, pistils and calyx) on another plate (potato-dextrose agar) for the detection of Gliocladium. After 8 days incubation at room temperature, observations of $G$. catenulatum were made using a stereomicroscope. At the same time also fungal pathogens causing storage rot were observed by following procedures described above.

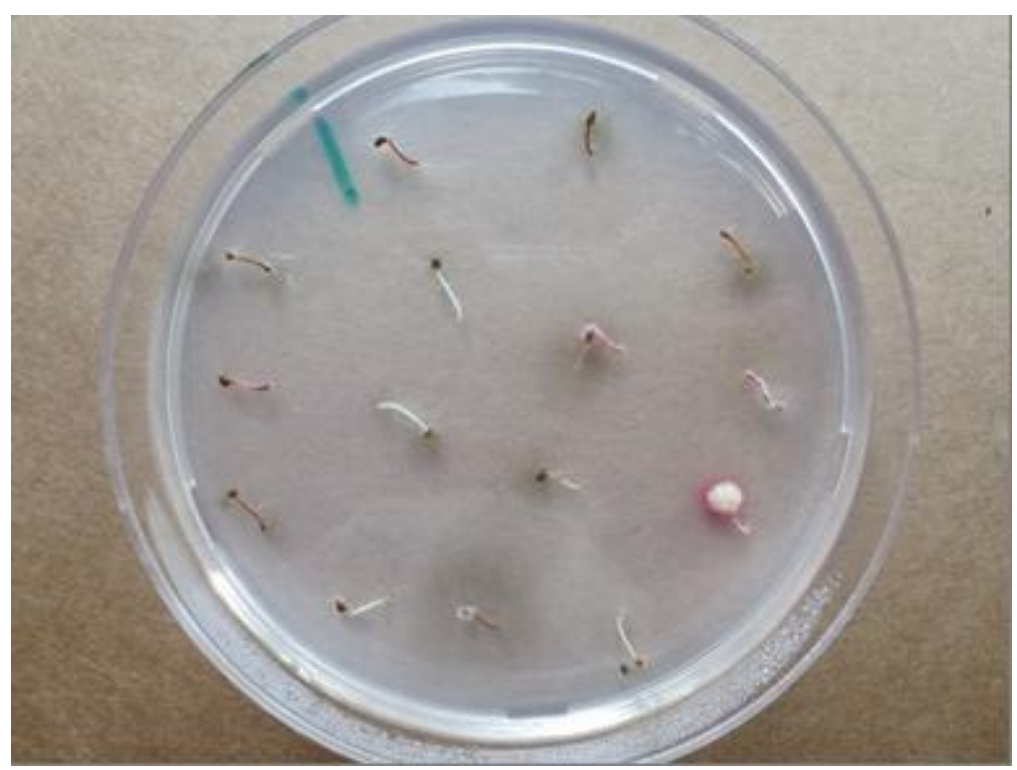

Figure 2. Stamens of apple flowers on water agar for microbial analysis

Photo: Marja-Leena Lahdenperä, Verdera Oy. 


\section{Results}

\subsection{Strawberry Results}

Strawberry efficacy results showed crop protection equalling or exceeding that provided by a full chemical fungicide program, under all weather conditions and over a wide geographical range (from Finland to Italy and Turkey, Table 2). Under heavy disease pressure ( $>25 \%$ diseased berries in untreated controls), entomovectoring provided on average of $47 \%$ disease reduction, which is the same as obtained by multiple fungicide sprays. Under light disease pressure (0-10\% diseased berries in untreated controls), biocontrol decreased grey mold on average by $66 \%$, which was more than the reduction from using fungicide sprays (Table 2). Biocontrol significantly reduced grey mold incidence from that in the untreated control in 20 out of the 23 field trials (Table 2).

Table 2. Field trial results using bee-disseminated precision biocontrol for the control of strawberry grey mold (Botrytis cinerea) by the antagonist Gliocladium catenulatum (Prestop ${ }^{\circledR}$ Mix). Honeybees were used as vectors in all countries, but in Estonia both honey bees (HB) and bumble bees (BB) were used

\begin{tabular}{|c|c|c|c|c|c|c|c|c|c|}
\hline \multirow[b]{2}{*}{ Country } & \multirow[b]{2}{*}{ Site } & \multirow[b]{2}{*}{ Year } & \multicolumn{4}{|c|}{ Grey mold proportion $^{1}$} & \multirow{2}{*}{$\begin{array}{l}\text { \% reduction } \\
\text { by Biocontrol }\end{array}$} & \multirow{2}{*}{ Sign. } & \multirow{2}{*}{ Citation } \\
\hline & & & Untreated & Fungicide & Biocontrol & F:cide+Bio & & & \\
\hline \multicolumn{10}{|c|}{ Light mold attack } \\
\hline Turkey & 1 & 2013 & 2.6 & & 0.8 & & 69 & & 1 \\
\hline Turkey & 1 & 2014 & 3.5 & & 0.9 & & 74 & & 1 \\
\hline Estonia & BB 1 & 2012 & 3.9 & & 0.2 & & 95 & & 2 \\
\hline Finland & 3 & 2006 & 5.8 & & 3.2 & & 45 & & 3 \\
\hline Estonia & HB 1 & 2011 & 6.0 & & 3.0 & & 50 & & 2 \\
\hline Finland & 5 & 2007 & 8.5 & & 3.0 & 1.8 & 65 & & 3 \\
\hline Finland & 2 & 2006 & 9.5 & 2.5 & & 0.8 & & & 3 \\
\hline Average & & & 5.7 & 2.5 & 1.8 & 1.3 & 66 & & \\
\hline \multicolumn{10}{|c|}{ Moderate mold attack } \\
\hline Finland & 4 & 2007 & 11.9 & & 7.8 & & 34 & & 3 \\
\hline Finland & 2 & 2007 & 12.0 & 4.0 & 7.0 & 4.2 & 42 & & 3 \\
\hline Estonia & BB 1 & 2013 & 14.5 & & 6.5 & & 55 & & 2 \\
\hline Finland & 3 & 2007 & 17.0 & & 9.1 & & 46 & & 3 \\
\hline Estonia & BB 2 & 2012 & 17.5 & & 5.5 & & 69 & & 2 \\
\hline Slovenia & 1 & 2014 & 19.0 & & 17.0 & & 11 & ns & 4 \\
\hline Finland & 1 & 2009 & 22.1 & 2.6 & 9.6 & 3.3 & 57 & & 3 \\
\hline Estonia & HB 1 & 2012 & 23.0 & & 15.0 & & 35 & & 2 \\
\hline Finland & 3 & 2008 & 24.0 & 9.0 & 8.0 & 3.0 & 67 & & 3 \\
\hline Finland & 3 & 2009 & 24.2 & & 14.9 & & 38 & & 3 \\
\hline Average & & & 18.5 & 5.2 & 10.0 & 3.5 & 45 & & \\
\hline \multicolumn{10}{|c|}{ Heavy mold attack } \\
\hline Finland & 1 & 2007 & 26.3 & 6.0 & 7.8 & 1.0 & 70 & & 3 \\
\hline Finland & 2 & 2009 & 38.5 & & 19.6 & & 49 & & 3 \\
\hline Italy & 1 & 2012 & 39.4 & 25.8 & 13.3 & 10.5 & 66 & & 5 \\
\hline Finland & 2 & 2008 & 40.0 & & 20.0 & & 50 & & 3 \\
\hline Finland & 1 & 2008 & 45.0 & 10.0 & 35.0 & 1.0 & 22 & ns & 3 \\
\hline Estonia & HB 1 & 2010 & 48.0 & & 38.0 & & 21 & ns & 2 \\
\hline Finland & 4 & 2009 & 50.3 & 46.0 & & & & & 3 \\
\hline Slovenia & 1 & 2013 & 55.0 & & 27.0 & & 51 & & 4 \\
\hline Finland & 1 & 2006 & & & 10.5 & 9.0 & & & 3 \\
\hline Average & & & 42.8 & 22.0 & 21.4 & 5.4 & 47 & & \\
\hline
\end{tabular}

Citation: 1 = Eken, 2014; 2 = Mänd et al., 2014; 3 = Hokkanen et al., 2014; 4 = Bevk, 2014; 5 = Maccagnani, 
2014.

${ }^{1}$ Values represent the proportion of moldy berries at the time of berry-picking at the main harvest. The column "\% reduction by Biocontrol" is the reduction in the proportion of moldy berries using entomovectored biocontrol, from that occurring in the untreated control. The reduction by Biocontrol was statistically significant in all but three trials, indicated as ' $n s$ ' in the Significance column.

\subsection{Raspberry Results}

Grey mold levels in the study year (2007) were moderate on raspberry, averaging $6 \%$ to $14 \%$. Honey beevectored biocontrol reduced disease by $42 \%$, on average, while the combined fungicide program together with bee-vectored biocontrol reduced the disease by $71 \%$ (Table 3 ). Unfortunately, no treatment with only fungicides was possible to arrange.

Table 3. Field trial overall results using bee-disseminated precision biocontrol for the control of the grey mold (Botrytis cinerea) by the antagonist Gliocladium catenulatum (Prestop ${ }^{\circledR}$ Mix) on raspberries in Finland in 2007

\section{Grey mold proportion ${ }^{1}$}

\begin{tabular}{lllll} 
& Untreated & Biocontrol & F:cide+Bio & $\begin{array}{l}\text { \% reduction } \\
\text { by Biocontrol }\end{array}$ \\
\hline Farm 1 & 6.9 & 2.7 & 2.1 & 61 \\
Farm 2 & 14 & 8.4 & 3.9 & 40 \\
Farm 3 & 9.2 & 4.9 & & 46 \\
Farm 4 & 9.7 & 6.1 & & 37 \\
Farm 5 & 6.1 & 4.5 & 2.0 & 26 \\
Average & $\mathbf{9 . 2}$ & $\mathbf{5 . 3}$ & $\mathbf{2 . 7}$ & $\mathbf{4 2 . 0}$ \\
\hline
\end{tabular}

\footnotetext{
${ }^{1}$ Values in the treatment columns are proportions of moldy berries of the total harvest. Last column gives the percent reduction in the proportion of moldy berries by biocontrol, compared with the untreated control. All reductions are statistically significant.
}

\subsection{Results on Apple Trees}

\subsubsection{Flower Analyses}

Analyses of apple flowers from treated trees revealed that the delivery of Prestop ${ }^{\circledR}$ Mix with the help of honeybees was successful in maintaining disease levels below economic thresholds. The examination showed that $50-75 \%$ of the apple flowers were colonized by Gliocladium, depending on the distance from the hive (Table 4, Figure 3). The antagonist was present in all flower organs (stamens, pistils, petals and calyx). No Gliocladium was detected in apple flowers collected from the untreated area.

In the flower analysis, the occurrence of the bio-control fungus, Gliocladium, and other pathogens were examined. No Botrytis cinerea was found on stamens, whereas Fusarium avenaceum occurred quite abundantly on stamens (Table 4, Figure 4). The percentage of $F$. avenaceum in the stamens was highest in the untreated reference flowers and lowest near the hive. When going further away from the hives, the amount of Fusarium increased approximately 2.5 -fold (from $10.7 \%$ to $26.0 \%$ ). 
Table 4. The occurrence of Gliocladium catenulatum in apple flowers after Prestop ${ }^{\circledR}$ Mix entomovectoring, and the effect of entomovectoring and distance from hive on the occurrence of Fusarium avenaceum in apple flowers

\begin{tabular}{lllllll}
\hline \multirow{2}{*}{$\begin{array}{l}\text { Treatment/Distance } \\
\text { from the hive }\end{array}$} & \multicolumn{2}{c}{ Gliocladium $\%$ in apple flowers } & & \multicolumn{2}{c}{ Fusarium in stamens } \\
\cline { 2 - 3 } & Stamens & Petals and pistils & Flowers & & $\%$ & Relative \\
\hline Untreated & 0 & 0 & 0 & & 26.0 & 100 \\
Prestop Mix (10m) & 18.3 & 22.0 & 75 & & 4.0 & 15 \\
Prestop Mix (50m) & 5.3 & 13.5 & 60 & & 7.3 & 28 \\
Prestop Mix (100m) & 5.7 & 9.5 & 50 & & 10.7 & 41 \\
\hline
\end{tabular}

\subsubsection{Apple storage Results}

The BCA, G. catenulatum, appeared to improve the shelf-life of apples. After Gliocladium treatment during flowering, apples were better preserved than fruits from the untreated reference (Table 5). After 3 months' storage (in January 2014), the Grade One yield was higher, and there was less core rot after the application of Prestop ${ }^{\circledR}$ Mix by entomovectoring, than in the controls. Also the proportion of apples in the category 'other damages' was reduced. Damages in question were mainly caused by unidentified diseases. One month later, in February 2014, the evaluation of the apples gave the same results, with greater differences between treated and untreated apple trees.

Table 5. The effect of Prestop ${ }^{\circledR}$ Mix entomovectoring on the quality of apples after 3-month (January 2014 ) and 4 month storage (February 2014)

\begin{tabular}{|c|c|c|c|c|}
\hline & \multicolumn{4}{|c|}{ Proportions (in \%) of apples after storage } \\
\hline & \multicolumn{2}{|c|}{ Entomovectored Prestop ${ }^{\circledR}$ Mix } & \multicolumn{2}{|c|}{ Untreated control } \\
\hline & 3 months & 4 months & 3 months & 4 months \\
\hline Grade One $^{1}$ & 76 & 72 & 66 & 59 \\
\hline Botrytis & 1 & 2 & 2 & 8 \\
\hline Fusarium & 2 & 0 & 2 & 1 \\
\hline Other damage & 22 & 26 & 30 & 32 \\
\hline
\end{tabular}

${ }^{1}$ Determined after EVIRA (2009).

The isolation tests on stored apples showed that, in Finland, Fusarium avenaceum was the main pathogen penetrating the developing fruit via the flower. However, part of the damage in apples is caused by Botrytis cinerea. 


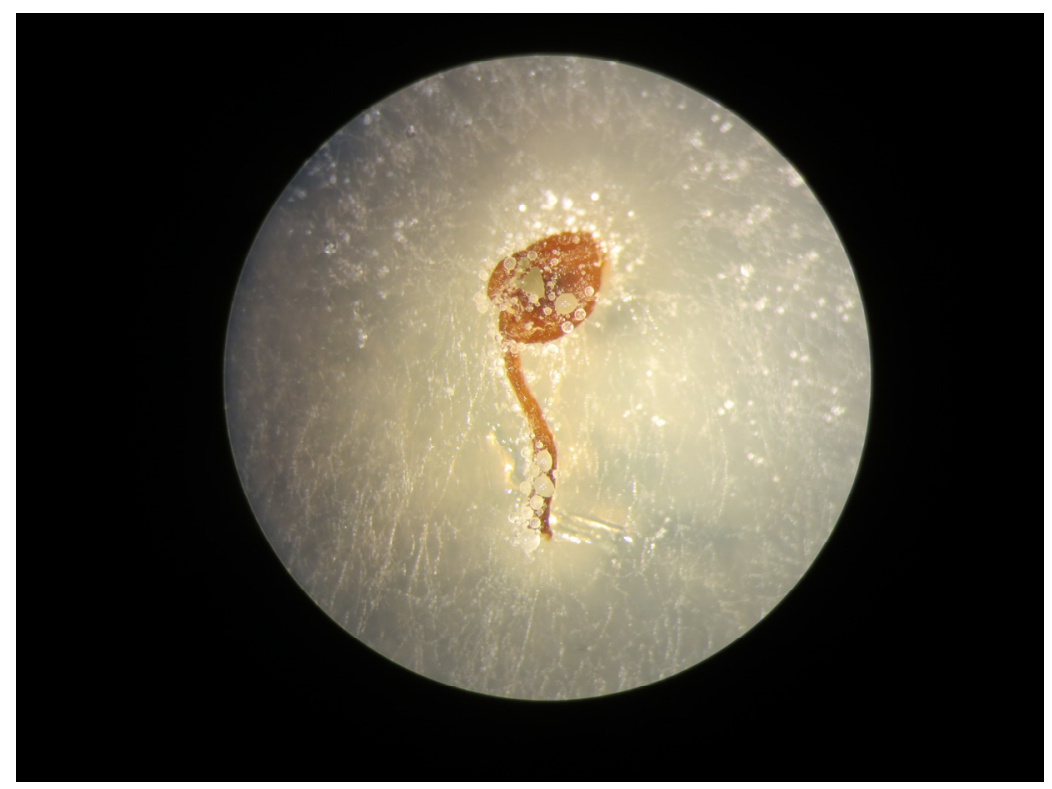

Figure 3. Gliocladium catenulatum colonizing a stamen from an apple flower Photo: Marja-Leena Lahdenperä, Verdera Oy

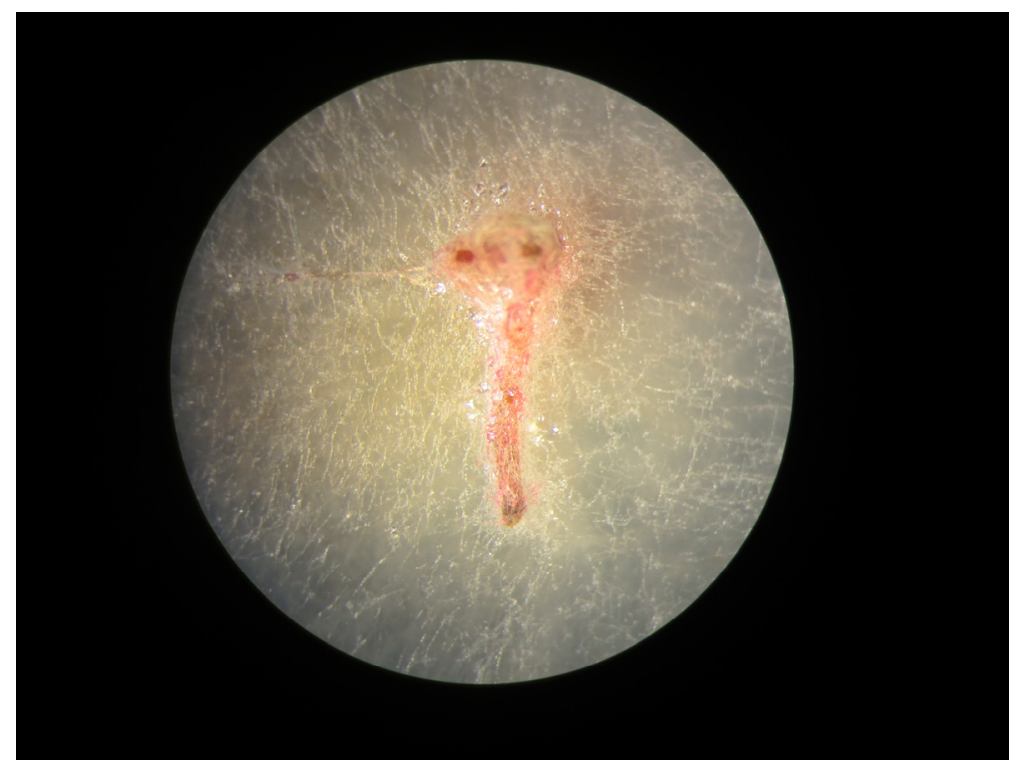

Figure 4. Fusarium avenaceum colonizing a stamen from an apple flower Photo: Marja-Leena Lahdenperä, Verdera Oy. 


\section{Discussion}

\subsection{Strawberry and Raspberry Grey Mold Control}

Peng et al. (1992) and Yu and Sutton (1997) reported good control of grey mold in raspberries and strawberries using Gliocladium roseum, reducing B. cinerea incidence from 90 to $68 \%$, and from 64 to $48 \%$, respectively. To our knowledge, results reported here represent the first successful use of entomovectoring by growers over large cropping areas. A review of entomovectoring (Mommaerts \& Smagghe, 2011) provided a listing of numerous other studies with a wide variety of target diseases, pests, crops, and antagonistic BCA, but could not identify practical applications in crop protection - other than our case in Finland. In the ERA-NET CORE ORGANIC 2 project BICOPOLL the group provided evidence that the control of $B$. cinerea on strawberry by using entomovectoring is possible across Europe, and that control results are similar to chemical fungicides. Furthermore, our Finnish on-farm research results with raspberry, reported here, confirmed that grey mold can be controlled with entomovectoring in commercial production of that crop as well.

Our results show that good efficacy in grey mold control can be achieved with Gliocladium catenulatum at much lower doses than what is required for equal efficacy when applying the BCA by spray treatments, thus resulting in economically competitive control (Lahdenperä, 2006; Lahdenperä, unpublished data). Using entomovectoring, $400 \mathrm{~g}$ of Prestop ${ }^{\circledR}$ Mix is disseminated/ha/season, but to achieve the same level of control by spraying the product would require about 1-2 kg/ha applied in 3-5 spray treatments (Lahdenperä, 2006; Lahdenperä, unpublished data). We assume that at least two factors contribute to this result: (i) blanket spraying of the crop at economically feasible doses does not bring high enough numbers of antagonist spores to the strawberry flowers when needed to prevent Botrytis from developing; and (ii) as at least some 40,000 new flowers open every day in a typical strawberry field per hectare (own calculations), these remain without protection until the next spraying is carried out. Entomovectoring appears to remedy both factors: (i) bees bring high amounts of BCA spores directly to the flower (several hundred spores have typically been measured after a bee visit, e.g., Peng et al., 1992; Yu \& Sutton, 1997) - enough to prevent the grey mold fungus from colonizing the flower; and (ii) bees are active every day, and visit flowers as soon as the weather conditions allow. This provides a continuous, targeted precision biocontrol to take place, and ensures thereby good protection against $B$. cinerea.

\subsection{Apple Core Rot Control}

Based on the first-year results of the apple trial, the biological efficacy and impact of Prestop ${ }^{\circledR}$ Mix applied through entomovectoring is considered successful for apple core rot management. The grower found it easy to deliver the microbial product with the dispenser attached to the beehive. Despite these promising results we have to keep in mind that core rot disease pressure was quite low due to the dry weather at the time of flowering. Therefore, conditions for fungal attack were not very favorable.

It is also interesting that the biocontrol method worked well while normal chemical pesticide programs were used on the experimental area. We can therefore indirectly conclude that with the bee-assisted Prestop ${ }^{\circledR}$ Mix treatment beneficial microbes have not been affected adversely. Chemical pesticides are usually sprayed early in the morning or late in the evening when bees are inside the hive, and not flying and spreading Gliocladium. Accordingly, this biological control is compatible with chemical treatments and can be used in integrated production.

Flower analysis showed reduced core rot. Apple flowers were colonized by G. catenulatum, so honeybees had successfully carried Prestop ${ }^{\circledR}$ Mix powder to the flowers. The antagonist was detected in stamens, pistils, petals and calyx.

The entomovectoring technique, i.e., a combination of Prestop ${ }^{\circledR}$ Mix and bees, is already commercially used for the control of grey mold (B. cinerea) on strawberry and raspberry. This part of the study shows that the bee-assisted system works also on apple against core rot (Fusarium avenaceum and B. cinerea). This indicates that the biocontrol method has potential to become an effective tool for the management of many other flower-transmitted diseases on various crops needing pollination by bees.

\subsection{Honey Bees vs. Bumble Bees}

In the literature there has been an unresolved debate concerning the relative merits of honey bees versus bumble bees as crop pollinators (e.g., Willmer et al., 1994), and this discussion refers also to entomovectoring situations. In the BICOPOLL project, we focused on the use of honey bees, but also investigated the potential of bumble bees and solitary bees for entomovectoring. We have established the reliability of honey bees, using the standard two-way dispenser BeeTreat ${ }^{\circledR}$ developed earlier in the pilot project. This system has been successfully used by some growers for nine years, and in recent years, by hundreds of other strawberry growers in Finland (Hokkanen, 
unpublished). In the BICOPOLL project, good control results in the open field using bumble bees were obtained in Estonia (Table 2), and in Finland, using Prestop ${ }^{\circledR}$ Mix delivered by bumble bees. However, at that time growers used self-made dispensers. In 2014, in Finland, some strawberry growers appear to have tested bumble bee hives with a new commercial dispenser for disseminating the BCA Prestop ${ }^{\circledR}$ Mix. A grower with 102 ha of strawberries purchased 150 bumble bee hives for entomovectoring, but unfortunately did not witness bee visits to his crop, nor dissemination of the antagonist (Koivistoinen, 2015; Taari, 2015). Due to cool weather the bumble bees apparently sealed the exits from their hive, and therefore did not disperse the BCA. The grower had used honey bee disseminated entomovectoring during the previous years, and had been satisfied with the result, but decided to test the application of bumble bees (Koivistoinen, 2015).

\subsection{Adoption of Entomovectoring for Wide-Scale Use}

Due to the successful results obtained in the BICOPOLL project, a significant shift is taking place in Finland that relates to the EU's Common Agricultural Policy (CAP) reform, and the associated legislation concerning environmental support to agriculture. In the new statutes, entomovectoring is specifically mentioned, under "Alternative crop protection in berry and fruit production" (Reskola, 2015). As of the 2015 growing season, conventional growers who commit to substituting chemical fungicide treatments with entomovectoring, for a minimum of 5 years, will receive $500 € /$ ha/year in environmental support (Reskola, 2015).

While we very much welcome this paradigm shift and the boost to environmental safety and entomovectoring, we would like to point out that all components of the system would need further research and development. This includes improved dispensers, BCA formulations, and the overall operations. Dispensers need to be improved to allow less frequent filling with the BCA. BCA formulations available for the moment have not been developed for entomovectoring, but for other uses, such as mixing into the soil. Although working adequately in practise, research in BICOPOLL has shown that formulations can be improved considerably for entomovectoring, allowing a better dispersal of the BCA in the target crop at a lower initial dose than what currently is used (Smagghe, 2014). More research needs to be carried out concerning the overall entomovectoring operation, such as placement and density of the bee hives, and hive conditioning allowing steering the foraging activity of the bees into our target crop. Conditioning possibilities include manipulation of the amount of pollen stored in the hive, and the number of open brood, which will determine whether the bees forage mainly for pollen, or for nectar. Strawberry cultivars vary in their attractiveness to bees (Ceuppens et al., 2015), but they all are primarily sources of pollen (protein), rather than nectar, to the bees. Furthermore, research in BICOPOLL showed that entomovectoring is enhanced if a diverse and abundant network of wild pollinators (e.g., Jedrzejewska-Szmek \& Zych, 2013; Vaudo et al., 2014) is maintained close to the target crop (Maccagnani, 2014). Such a pollinator network facilitates secondary spread of the BCA, ensuring a more complete and even dissemination of the BCA in the crop.

In addition to these research and development needs, all parties involved must work together in order to make full use of the entomovectoring technique: for that the berry and fruit growers are recommended to (i) keep bees themselves, or to hire local beekeepers' services from entomovectoring; and (ii) manage vegetation within and around the target crop to support the activity of bees and other pollinators, which can help to disseminate the beneficial microbes within the crop. Beekeepers are recommended to (i) market pollination and biocontrol services to fruit and berry growers, and (ii) in the management of bees and the dissemination activity to ensure that all operations are effective in mananging bees and their microbe dissemination activity. Biocontrol product manufacturers are recommended to develop products and their formulations specifically for entomovectoring, and regulators are recommended to register, and to promote the registration of biocontrol products, which are needed for effective control of target diseases and pests amenable to entomovectoring. In all project countries we experienced that the lack of registered BCA products is a major bottleneck to adopting these techniques more widely.

What should be avoided, in particular in Finland as a pilot country officially supporting the adoption of entomovectoring, is an unguided and hasty uptake of the technology. Conventional crop protection using chemical pesticides is highly regulated and guided: operators need to be trained and have to take exams, machinery needs to be approved and inspected, and abundant advisory service help is offered so that the crop protection operations have the highest possible chance to be successful. Although the initial adoption of entomovectoring by the pioneering growers has taken place predominantly without problems, a wider uptake may face increasing crop protection failures unless more attention is paid to training all stakeholders.

Entomovectoring offers to organic growers for the first time an economically feasible tool to protect their berry crops against the grey mold disease, as well as an opportunity to manage diseases such as the core rot on apples. 
This improves the competitiveness of organic berry and fruit growing, and provides a positive image, which can be utilized in marketing of the products, as already is happening in Finland (e.g. by using the slogan "Enjoy the fruits of entomovectoring pioneers", Aasatek Oy, Finland).

\section{Acknowledgments}

Financial support to BICOPOLL from the EU ERA-NET project CORE ORGANIC 2, and to the project "Entomovectoring in plant protection" from NordForsk, and to the project BICOPOLL-NET from NordForsk, is gratefully acknowledged. We thank all partners and collaborators in BICOPOLL for their contributions and support, and all the berry and fruit growers on whose fields our experiments have been carried out. We thank a critical reviewer for comments, which clarified and imporved our paper significantly. Financial support from the OECD to HH for allowing these results to be presented at the workshop "Innovations in Organic Food Systems for Sustainable Production and Enhanced Ecosystem Services", is acknowledged with thanks.

\section{References}

Agriculture and Agri-Food Canada. (2009). Crop Profile for Strawberry in Canada. Retrieved from http://dsp-psd.pwgsc.gc.ca/collection_2009/agr/A118-10-17-2005E.pdf

Bevk, D. (2014). BICOPOLL Final Report for Slovenia. BICOPOLL Final Meeting, 22-26 September 2014, Åland Islands, Finland.

Ceuppens, B., Ameye, M., Van Langenhove, H., Roldan-Ruiz, I., \& Smagghe, G. (2015). Characterization of volatiles in strawberry varieties 'Elsanta' and 'Sonata' and their effect on bumblebee flower visiting. Arthropod-Plant Interact 9 (in press). http://dx.doi.org/10.1007/s11829-015-9375-y

Eken, C. (2014). BICOPOLL Final Report for Turkey. BICOPOLL Final Meeting, 22-26 September 2014, Åland Islands, Finland.

European Commission. (2014). Commission staff working document. Impact assessment, accompanying the document Proposal for a Regulation of the European Parliament and of the Council on organic production and labelling of organic products. $\operatorname{COM}(2014) 180$ final. Annexes 1-8. Retrieved from http://ec.europa.eu/agriculture/organic/documents/eu-policy/policy-development/impact-assessment/impact -assessment-part2_en.pdf

EVIRA. (2009). Tuoreiden hedelmien ja vihannesten kaupan pitämistä koskevat vaatimukset. Eviran ohje 18103/1, 1.7.2009. The Finnish Food Safety Authority. Retrieved from http://www.evira.fi/files/attachments/fi/elintarvikkeet/valmistus_ja_myynti/kasvikset/heviohje_netti_01012 010.pdf

FAO. (2011). FAOSTAT agricultural production statistics. Retrieved from http://faostat.fao.org/site/567/ and http://faostat.fao.org/site/339/

Hokkanen, H. M. T., \& Menzler-Hokkanen, I. (2007). Use of honeybees in the biological control of plant diseases. Entomol Res, 37, A62-A63. http://dx.doi.org/10.1111/j.1748-5967.2007.00115.x

Hokkanen, H. M. T., Menzler-Hokkanen, I., \& Levy, M. (2014). BICOPOLL Final Report for Finland. BICOPOLL Final Meeting, 22-26 September 2014, Åland Islands, Finland.

IPMCenters. (2011). Crop Profile for Strawberries in Louisiana. Retrieved from http://www.ipmcenters.org/cropprofiles/docs/LAstrawberries.pdf

Jedrzejewska-Szmek, K., \& Zych, M. (2013). Flower-visitor and pollen transport networks in a large city: $\begin{array}{llll}\text { Structure and } & \text { properties. }\end{array}$ http://dx.doi.org/10.1007/s11829-013-9274-z

Kevan, P. G., Kapongo, J.-P., Al-mazra'awi, M., \& Shipp, L. (2008). Honey bees, bumble bees and biocontrol. In R. R. James \& T. Pitts-Singer (Eds.), Bee pollination in agriculture ecosystems. New York: Oxford University Press.

Koivistoinen, V. (2015). Kokemuksia kimalaispölytyksestä avomaalla [Experiences on bumble bee pollination in open field]. Suomen Mehiläishoitajain Liitto, Talvipäivät 24.1.2015. Retrieved from http://www.mehilaishoitajat.fi/?x118281=1960902

Lahdenperä, M.-L. (2006). Gliocladium catenulatum as an antagonist against grey mold on strawberry. NJF seminar No. 389: Pest disease and weed management in strawberry. 8-9. Nov. 2006, Finland. Abstract in NJF Report no. 10, 2006. 
Maccagnani, B. (2014). BICOPOLL Final Report for Italy. BICOPOLL Final Meeting, 22-26 September 2014, Åland Islands, Finland.

Mänd, M., Karise, R., \& Muljar, R. (2014). BICOPOLL Final Report for Estonia. BICOPOLL Final Meeting, 22-26 September 2014, Åland Islands, Finland.

Mommaerts, V., \& Smagghe, G. (2011). Entomovectoring in plant protection. Arthropod-Plant Interactions, 5(2), 81-95. http://dx.doi.org/10.1007/s11829-011-9123-x

Mommaerts, V., Put, K., \& Smagghe, G. (2011). Bombus terrestris as pollinator-and-vector to suppress Botrytis cinerea in greenhouse strawberry. Pest Management Science, 67(March), 1069-1075. http://dx.doi.org/10.1002/ps.2147

Nallathambi, P., Ulmamaheswari, C., Thakore, B. B. L., \& More, T. A. (2009). Post-harvest management of ber (Ziziphus mauritiana Lamk) fruit rot (Alternaria alternata Fr. Keissler) using Trichoderma species, fungicides and their combinations. Crop Prot, 28, 525-532. http://dx.doi.org/10.1016/j.cropro.2009.02.002

Narayanasamy, P. (2011). Microbial Plant Pathogens-Detection and Disease Diagnosis: 5. Fungal Pathogens, Vol. 1, Springer. http://dx.doi.org/10.1007/978-90-481-9735-4_2

Peng, G., Sutton, J. C., \& Kevan, P. G. (1992). Effectiveness of honeybees for applying the biocontrol agent Gliocladium rosea to strawberry flowers to suppress Botrytis cinerea. Can J Plant Pathol, 14, 117-129. http://dx.doi.org/10.1080/07060669209500888

Reskola, V.-P. (2015). Ympäristökorvaus käynnistymässä [Environmental subsidies are being started]. Puutarha \& Kauppa 3/2015, p. 14.

Smagghe, G. (2014). BICOPOLL Final Report for Belgium. BICOPOLL Final Meeting, 22-26 September 2014, Åland Islands, Finland.

Smagghe, G., Mommaerts, V., Hokkanen, H., \& Menzler-Hokkanen, I. (2012). Multitrophic interactions: the entomovector technology. In G. Smagghe \& I. Diaz (Eds. Chapter 5) Arthropod-Plant Interactions: Novel Insights and Approaches for IPM. Progress in Biological Control 14. Springer. http://dx.doi.org/10.1007/978-94-007-3873-7_5

Strømeng, G. M. (2008) Aspects of the biology of Botrytis cinerea in strawberry (Fragaria x ananassa) and alternative methods for disease control. Norwegian University of Life Sciences, Philosophiae Doctor (PhD) Thesis 2008: 56

Taari, J. (2015). Kimalaiset eivät hoitaneet hommiaan, asiasta riidellään oikeudessa [Bumble bees did not do their job, the issue is being quarreled at court]. Etelä-Suomen Sanomat 25.1.2015. Retrieved from http://www.ess.fi/uutiset/kotimaa/2015/01/25/kimalaiset-eivat-hoitaneet-hommiaan-asiasta-riidellaan-oikeu dessa

Vaudo, A. D., Patch, H.-M., Mortensen, D. A., Grozinger, C. M., \& Tooker, J. F. (2014). Bumble bees exhibit daily behavioral patterns in pollen foraging. Arthropod-Plant Interactions, 8, 273-283. http://dx.doi.org/10.1007/s11829-014-9312-5

Willmer, P. G., Bataw, A. A. M., \& Hughes, J. P. (1994). The superiority of bumblebees to honeybees as pollinators: insect visits to raspberry flowers. Ecological Entomology, 19, 271-284. http://dx.doi.org/10.1111/j.1365-2311.1994.tb00419.x

Yu, H., \& Sutton, J. C. (1997). Effectiveness of bumblebees and honeybees for delivering inoculum of Gliocladium roseum to raspberry flowers to control Botrytis cinerea. Biol. Control, 10, 113-122. http://dx.doi.org/10.1006/bcon.1997.0562

\section{Copyrights}

Copyright for this article is retained by the author(s), with first publication rights granted to the journal.

This is an open-access article distributed under the terms and conditions of the Creative Commons Attribution license (http://creativecommons.org/licenses/by/3.0/). 